\title{
Does Whole Body Vibration Restore Immobilization-Induced Suppression in AMPK Activation
}

\author{
Tüm Vücut Titreşimi İmmobilizasyon ile Azalan \\ AMPK Aktivasyonunu Arttırır mı?
}

\author{
Şenay Akın¹, Gürhan Dönmez², Mustafa Özdemir ${ }^{1}$, Haydar A. Demirel ${ }^{1}$ \\ ${ }^{1}$ Exercise and Sport Physiology Department, Faculty of Sport Sciences, Hacettepe University, Ankara, Turkey \\ ${ }^{2}$ Sports Medicine Department, Faculty of Medicine, Hacettepe University, Ankara, Turkey
}

\section{Ş. Akın \\ 0000-0001-5729-5944 \\ G. Dönmez \\ 0000-0001-6379-669X \\ M. Özdemir \\ 0000-0003-3512-1147 \\ H.A. Demirel \\ 0000-0002-0629-8229}

Geliş Tarihi / Date Received: 16.04.2018

Kabul Tarihi /Date Accepted: 01.05.2018

Yaym Tarihi /Published Online: 23.05.2018

\section{Yazışma Adresi /}

Corresponding Author:

Şenay Akın

Hacettepe University, Faculty of Sport Sciences, Exercise and Sport Physiology

Department, Ankara, Turkey

E-mail: senaya@hacettepe.edu.tr

(C)2018 Türkiye Spor Hekimleri Derneği. Tüm hakları saklıdır.

\begin{abstract}
Objective: AMP activated kinase (AMPK) is involved in mitochondrial biogenesis, glucose transport and stimulates free fatty acid oxidation. Physical inactivity has been shown to increase incidence of metabolic diseases by decreasing the phosphorylation of AMPK. On the other hand, activation of AMPK via exercise training results in the reduction of insulin resistance. Currently, whole body vibration (WBV) is widely used to improve health, and has been proven to be effective to increase bone mineral density and muscle strength. Inactivity is inevitable especially during long-term bed rest or following sports injuries, and WBV may be an alternative strategy to improve muscle fitness and metabolic conditions. Therefore, this study aimed to elucidate the effects of WBV on AMPK, which plays an important role for cellular energy balance.

Materials and Methods: 30 Wistar rats were assigned to one of the following groups ( $n=6$ per group): Control (C), Immobilization (I), Immobilization+Remobilization (IR), Immobilization+WBV (IV), WBV (V). Immobilization was obtained through two weeks of bilateral leg casting. $V$ groups underwent one week of $45 \mathrm{~Hz}, 3 \mathrm{~mm}$ Amp, 20min/day WBV. Animals in IR group underwent one week of remobilization following immobilization and animals in IV group underwent one week of WBV treatment during remobilization period following the initial two weeks of immobilization. At the end of the experimental procedure, soleus muscles were isolated, and mRNA, AMPK and p-AMPK levels were determined.

Results: There were no differences in mRNA levels among groups. On the other hand, $p$ AMPK/AMPK ratio significantly decreased after two weeks of immobilization $(p<0.05)$. Whole body vibration resulted in increased levels of $p$-AMPK/AMPK ratio in group IV compared with the immobilization only group $(p<0.001)$.
\end{abstract}

Conclusions: With these findings we have shown for the first time that immobilizationinduced decreases in AMPK activation could be restored by WBV application during a remobilization period. Therefore, WBV may play a role in preventing impairment of disuse induced metabolic functions.

Keyword: Whole body vibration, immobilization, casting, skeletal muscle, AMPK

öz

Amaç: AMP ile aktive olan protein kinaz (AMPK); mitokondri biyogenezi, glukoz transportu ve serbest yağ asidi oksidasyonunu uyaran bir moleküldür. İnaktivitenin AMPK fosforilasyonunu önleyerek birçok metabolik hastalığa zemin hazırladığı, egzersizin 
insülin direncini azaltmak gibi olumlu etkilerini AMPK aktivasyonu yoluyla gerçekleştirdiği düşünülmektedir. Günümüzde tüm vücut titreşimi (TVT) sağlığın korunması ve geliştirilmesi amacıyla yaygın olarak kullanılmakta olup, kemik mineral yoğunluğu ve kas kuvvetinde artışa yol açmaktadır. Özellikle uzun süreli yatak istirahatleri veya spor yaralanmaları gibi zorunlu inaktivite sonrası kas dokusunun toparlanması ve hareketsizliğin neden olduğu metabolik sorunlarının iyileştirilmesinde TVT uygulamasının alternatif bir yöntem olabileceğinden yola çıkan bu çalışma ile, immobilizasyon sonrasında TVT uygulamasının kas hücresi enerji dengesinde anahtar rol oynayan AMPK üzerine etkisinin belirlenmesi amaçlandı.

Gereç ve Yöntemler: Çalışmada 30 adet sıçan Kontrol (K), İmmobilizasyon (i), İmmobilizasyon+Remobilizasyon (iR), İmmobilizasyon+Titreşim (IT), Titreşim ( $T$ ) olmak üzere rastgele beş farklı gruba ( $n=6 / g r u p)$ ayrıldı. Kontrol grubuna hiçbir uygulama yapılmazken; T grubuna 1 hafta TVT, i grubuna iki hafta immobilizasyon, iR grubuna iki haftalık immobilizasyonu takiben bir haftalık remobilizasyon, iT grubuna ise iki haftalık immobilizasyon sonrası bir hafta TVT uygulandı. İmmobilizasyon gruplarındaki sıçanlar iki hafta süresince bilateral alçıya alındı. Titreşim grubundaki sıçanlara $45 \mathrm{~Hz}, 3 \mathrm{~mm}$ genlik, 20dk/gün TVT uygulandı. Deney sonunda soleus kasları izole edilerek AMPK gen ekspresyonu ile fosforile ve total AMPK protein düzeyleri belirlendi.

Bulgular: Gruplar arasında mRNA düzeyleri açısından bir fark bulunmazken; pAMPK/AMPK oranı immobilizasyon grubunda azaldı $(p<0,05)$, remobilizasyon sonrası TVT uygulanan grupta ise immobilizasyon grubuna göre anlamlı ölçüde arttı $(p<0,001)$.

Sonuçlar: $\mathrm{Bu}$ çalışma ile immobilizasyonda görülen azalmış AMPK aktivasyonunun remobilizasyon döneminde uygulanan TVT ile arttığı ilk kez ortaya konmuş olup, bu sonuçlar TVT'nin metabolik fonksiyon bozukluklarının önlenmesinde rol oynayabileceğini düşündürmektedir.

Anahtar kelimeler: Titreşim, immobilizasyon, alçı, iskelet kası, AMPK

Available at: http://journalofsportsmedicine.org and http://dx.doi.org/10.5152/tjsm.2018.107

Cite this article as: Akin S, Donmez G, Ozdemir $M$ et al. Does whole body vibration restore immobilization-induced suppression in AMPK activation? Turk J Sports Med. 2018;53(4):174-81.

\section{GíRiş}

AMP ile aktive olan protein kinaz (AMPK), hücre içerisindeki enerji dengesini algılayan ve buna ilişkin hücresel sinyaller oluşturan bir proteindir. AMPK'nin fosforilasyonla aktive olduğu (pAMPK), p-AMPK'nin özellikle iskelet kaslarında glukoz alımında görev alan GLUT4 proteinlerinin sentezini artırdığı ve aynı zamanda biyosentez yolaklarında yer alan bazı enzimlerin inaktivasyonuna neden olarak ATP kullanımını azalttığı bilinmektedir (1). Böylece AMPK aktivasyonu ile bir yandan ATP sentezi için kas içerisine glukoz alımı uyarılırken, diğer yandan ATP gerektiren anabolik süreçlerin inhibisyonu da sağlanmış olur $(2,3)$. Glukoz yetersizliği ve hipoksi gibi sınırlı ATP üretimine neden olan stresler AMP/ATP ve $\mathrm{Cr} / \mathrm{PCr}$ oranında artışa neden olarak AMPK aktivasyonunu sağlarken (4), insülin direnci, obezite ve metabolik hastalıklara neden olan aşırı beslenme ve inaktivite, düşük AMPK aktivasyonu ile karakterizedir (5).

Düzenli egzersizlerin insulin direncini azalttığ (6) erken ölümleri ve morbiditeyi önlediği (7) iyi bilinmektedir. Diğer yandan, fiziksel inaktivite ve sedanter yaşam bir çok kronik hastalık için ciddi bir risk faktörüdür (8). İnsülin aracılı glu- koz uzaklaştırılmasından sorumlu en önemli doku olması nedeni ile iskelet kas kütlesinin korunmasının, insülin direnci ve tip 2 diyabetin önlenmesi başta olmak üzere kronik hastalıkların önlenmesinde önemli bir yeri vardır (9). Egzersiz sırasında gerçekleştirilen düzenli kas kontraksiyonları, metabolik bir stress olarak AMP/ATP oranını artırarak AMPK aktivasyonuna neden olmaktadır $(10,11)$.

Spor yaralanmaları sonrası ekstremite hareketlerinin kısıtlandığı alçı, atel ve yatak istirahati gibi tedavi uygulamalarının yol açtığı kas kütle ve fonksiyon kaybı nedeniyle spora geri dönme sürecinde gecikmelere neden olduğu iyi bilinmektedir. Diğer yandan günlük adım sayısının sadece bir hafta süreyle düşürülmesinin insülin direncinde \%53'lük artışa neden olması (12), immobilizasyon nedeni ile görülen kas kuvvet ve fonksiyon kaybına iskelet kası metabolizmasındaki değişikliklerin de eşlik edeceğini düşündürmektedir.

AMPK aktivasyonunun alçı yoluyla oluşturulan immobilizasyondan nasıl etkilendiği bilinmemekle beraber, sıçanda kuyruktan asma yoluyla oluşturulan atrofi modelinde AMPK fosforilasyonunun ve enerji depolarının azaldığı; protein 
döngüsünün ise yıkım yönünde değiştiği bilinmektedir (13). Bu bulgular, herhangi bir spor yaralanması nedeni ile alçı veya atele alınarak immobilize edilen bölgede enerji düzeyini algılayan AMPK aktivasyonunun azalacağını ve bu durumun iskelet kası metabolik fonksiyonlarını bozarak iyileşme sürecini olumsuz etkileyeceğini düşündürmektedir.

İskelet kası mekanik sinyale duyarlıdır. Özellikle herhangi bir nedenle egzersiz yapmanın mümkün olmadığı durumlarda egzersize alternatif olarak tüm vücut titreşimi uygulaması düşünülebilir (14). Son yıllarda, tüm vücut titreşiminin (TVT) kassal performansı artırmak için rehabilitasyon programları içerisinde kullanımının giderek yaygınlaștığı (15) ve egzersizin yaptığı etkileri mimik ederek, kemik mineral yoğunluğu, kas kütle ve kuvvetini artırdığı ifade edilmektedir (16). TVT'nin iskelet kasında yağ infiltrasyonunu ve adipojenik gen ekspresyonunu azalttı̆̆ $(17,18)$; leptin reseptörü olmayan $\mathrm{db} / \mathrm{db}$ farelerde TVT'nin koşu egzersizine benzer biçimde yağ hücresi hipertrofisini ve hepatik lipit içeriğini azalttığı ve kas lif enine kesit alanını artırdığı bildirilmiştir (19). Bu sonuçlar özellikle yüksek frekanslı ve düşük genlikli titreşimin, spor yaralanmaları nedeni ile bir ekstremitenin alçı veya atele alınmasını gerektiren durumlarda, immobilizasyonun sonlandırılmasını takip eden toparlanma sürecinde kas atrofisinin azaltılması, kas kuvveti ve metabolik fonksiyonlarının daha hızlı kazanılmasında etkili olabileceğini düşündürmektedir.

$\mathrm{Bu}$ çalışma, alçı yoluyla gerçekleştirilen immobilizasyonun AMPK aktivasyonunda azalmaya neden olacağı ve remobilizasyon döneminde TVT uygulanmasinin ise AMPK aktivasyonunun artırılmasına katkı sağlayacağı hipotezlerini test etmeyi amaçlamaktadır.

\section{GEREÇ ve YÖNTEMLER}

\section{Deney Guplarl:}

$\mathrm{Bu}$ çalışmada Hacettepe Üniversitesi Hayvan Deneyleri Yerel Etik Kurulu tarafindan 2010-42 sayılı etik kurul onayı verilmiş hayvanlardan izole edilerek saklanan kas dokuları kullanılmıştır. Çalışmada 30 adet 200-250g ağırlığında Wistar Albino (4-6 aylık dişi sıçan); a) kontrol grubu $(K, n=6)$, b) iki hafta immobilizasyon grubu (i, $n=6$ ), c) iki hafta immobilizas- yonu takip eden bir hafta remobilizasyon grubu (İR, n=6), d) iki hafta immobilizasyonu takip eden bir haftalık remobilizasyon döneminde tüm vücut titreşimi uygulanan grup (İT, $n=6$ ), ve bir hafta tüm vücut titreşimi uygulanan grup $(\mathrm{T}, \mathrm{n}=6)$ olmak üzere beş ayrı gruba ayrıldı. Çalışma deseni ve gruplara yapılan uygulamalar ayrıntılı olarak bir başka çalışmada verilmiş olup aşağıda kısaca açıklanmıştır (20). Buna göre İ, İR ve İT gruplarında alçı yolu ile 2 haftalık immobilizasyon gerçekleştirilirken; İT grubu sıçanlar iki haftalık immobilizasyonu takip eden bir haftalık remobilizasyon döneminde, İT grubu sıçanlar ise herhangi bir immobilizasyon uygulanmadan bir haftalık tüm vücut titreşimi uygulamasına tabi tutuldular. İ grubu sıçanlar iki haftalık alçılama sonrasında K grubu sıçanlarla birlikte ötenazi edilirken; İR ve İT grubu sıçanlar iki haftalık alçılama sonrasındaki bir haftalık remobilizasyon dönemi sonunda, $\mathrm{T}$ grubu sıçanlar ise bu iki grupla eş zamanlı olarak bir haftalık TVT uygulaması sonunda ötenazi edildi.

\section{Alçı uygulaması:}

İ ve İR gruplarındaki hayvanlar kısa süreli anestezi (90 mg/kg Ketamin $+10 \mathrm{mg} / \mathrm{kg}$ ksilazin, ip) ile uyutulduktan sonra ayak bileği plantar fleksiyona gelecek şekilde alt ekstremiteleri gövdeden itibaren gluteal bölge serbest bırakılarak Paris alçısı ile bilateral alçıya alındı ve sıçanların alçıya kemirerek zarar vermesini engellemek için ise Paris alçısının üzerinden Scotchcast Plus ıslak hafif alçı geçirildi.

\section{Tüm Vücut Titreşimi Uygulaması:}

Titreşim grubundaki sıçanlar (İT ve T grupları) bir hafta boyunca her gün aynı saatte $45 \mathrm{~Hz}$ frekans ve $3 \mathrm{~mm}$ genlikte $1 \mathrm{dk}$ TVT $1 \mathrm{dk}$ dinlenim şeklinde aralıklı TVT uygulamasına tabi tutuldu. Buna göre hayvanların platforma ve olası strese adaptasyonu için titreşim uygulaması ilk gün $15 \mathrm{dk}$ yapılırken, süre kademeli olarak her gün $5 \mathrm{dk}$ artırılarak 4-7 günler arasında günde $30 \mathrm{dk}$ TVT uygulanacak şekilde gerçekleştirildi.

\section{Doku İzolasyonu:}

Sıçanlar intraperitonel pentobarbital sodyum $(100 \mathrm{mg} / \mathrm{kg})$ enjeksiyonu yolu ile ötenazi edilerek, soleus kası izolasyonu gerçekleştirildi. Dokular analiz edilinceye kadar $-80^{\circ} \mathrm{C}$ derin dondurucuda saklandı. 


\section{Gen Ekspresyonu analizi:}

Yaklaşık 50mg soleus kasından TRIzol metodu (Life Technologies, Grand Island, NY) ile RNA izolasyonu yapıldı. Elde edilen RNA'lar cDNA'ya çevirildikten sonra RT-PCR (Gerçek ZamanlıPolimeraz Zincir Reaksiyonu) ile gen ekspresyon analizi için hazırlandı (ViiA 7, Applied Biosystems). AMPK ve $\beta$-aktin'e ilişkin gen ekspresyonları Applied Biosystem'dan temin edilen gen ekspresyon assay ile belirlendi (sırasiyla Rn00576935m1 ve Rn00667869m1). $\beta$-aktin, AMPK ekspresyonunun normalizasyonunda gardiyan gen (housekeeping gen) olarak kullanıldı.

\section{Örneklerin Hazırlanışı:}

Yaklaşık 50mg soleus kası 10 kat volümdeki homojenizasyon tamponu $(50 \mathrm{mM}$ Tris $\mathrm{HCl}$, $100 \mathrm{mM} \quad \mathrm{NaF}, 10 \mathrm{mM}$ EDTA, $50 \mathrm{mM} \quad \beta-$ gliserofosfat, $1 \mathrm{Mm}$ Na3V04, 3mM benzamadin, $1 \mathrm{Mm}$ PMSF ve $10 \mu \mathrm{g} / \mathrm{ml}$ aprotonin, $10 \mu \mathrm{g} / \mathrm{ml} \mathrm{leu}-$ peptin ve $10 \mu \mathrm{g} / \mathrm{ml}$ pepsitatin) ile homojenize edildi. Homojenatlar $10.000 \mathrm{xg}$ 'de $10 \mathrm{dk}$ süresince $4^{\circ} \mathrm{C}^{\prime}$ de santrifüj edildikten sonra elde edilen süpernatantlar $-80^{\circ} \mathrm{C}$ dondurucuda analiz edilinceye kadar saklandı. Süpernatantların içerdiği protein miktarı Bradford yöntemi ile belirlendi.

\section{Immunoblot:}

Eşit miktarlardaki protein $(50 \mu \mathrm{g}), \% 12$ lik SDSPAGE kullanılarak ayrıştırıldı. Jel elektroforezi sonrasında proteinler yarı kuru transfer sistemi (Trans-Blot Turbo, BioRad) ile nitroselüloz membranlara (BioRad) transfer edildi. Blotlama işlemi için membranlar TTBS (Tween 20+Trissalin) içerisinde $\% 5^{\prime}$ lik kuru süt ile 1 saat oda sıcaklığında bloklandıktan sonra total AMPK (AMPK alfa alt ünitesi) ve fosforile AMPK (alfa alt ünitesi Thr 172 fosforilasyonu) için birincil antikorlar (Cell Signaling Technologies) ile $4^{\circ} \mathrm{C}^{\prime}$ de gece boyunca inkübasyonu sağlandı. Membranların 3 defa 5'er dakika TTBS ile ylkamalarından sonra anti-rabbit ve anti-mouse horse-radish peroksidaza konjuge ikincil antikorlar (Amersham Biosciences) ile 1 saat oda sıcaklığında inkübe edildi. Protein bantları kemilüminesans substrat (Clarity Max Western ECL Blotting Substrate, Bio-Rad) kullanılarak görüntülendi ve bantların miktar olarak tayinleri bilgisayarlı görüntü analiz sistemi ile saptandı.

\section{Verilerin Analizi}

Çalışmada grupların karşılaştırılmasında Tek Yönlü Varyans Analizi ve ikili karşılaștırmalar için ise Tukey post hoc testi kullanıldı. Tüm istatistiksel analizlerde $\mathrm{p}<0,05$ düzeyi anlamlı olarak kabul edildi.

\section{BULGULAR}

AMPK mRNA düzeyleri açısından kontrol, immobilizasyon, immobilizasyonu takiben bir haftalık remobilizasyon, immobilizasyonu takip eden bir haftalık remobilizasyon döneminde TVT uygulanan ve sadece bir haftalık TVT uygulanan gruplar arasında istatistiksel olarak anlamlı bir fark bulunamadı ( $p>0,05)$. Her ne kadar remobilizasyon döneminde TVT uygulanan grupta (IT grubu) AMPK mRNA düzeyleri İ ve İR gruplarına göre \%60 civarında daha yüksek görülüyorsa da, bu artış istatistiksel olarak anlamlı değildi (Şekil 1).

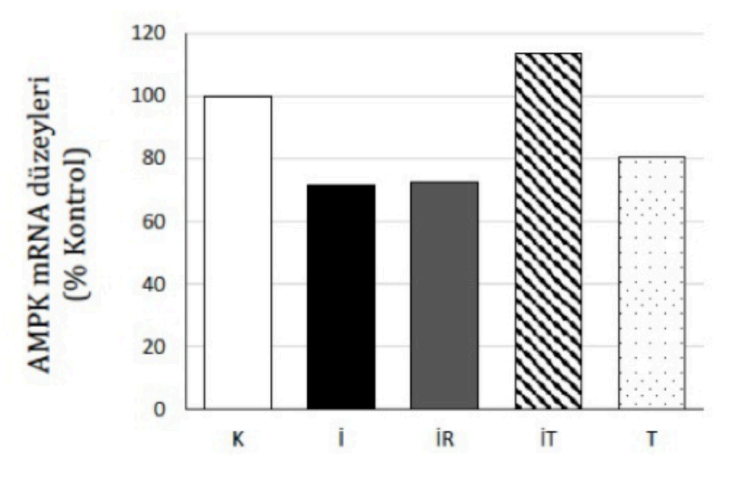

Şekil 1. İmmobilizasyon, immobilizasyon sonrası remobilizasyon ve TVT uygulamasının AMPK gen ekspresyonu üzerine etkisi. Gruplar arasında istatistiksel olarak anlamlı bir fark yoktur $(\mathrm{p}<0,05)$. Gruplar sirası ile ( $\mathrm{n}=6$, her gup); K: kontrol, İ: iki haftalık immobilizasyon, İR: iki haftalık immobilizasyonu takip eden bir hafta remobilizasyon, İT: iki haftalık immobilizasyonu takip eden remobilizasyon döneminde bir hafta TVT uygulanan grup, T: bir hafta TVT uygulanan grup.

Şekil 2'de fosforile ve total AMPK protein düzeyleri verilmektedir. Buna göre, alçı yolu ile oluşturulan iki haftalık immobilizasyon AMPK aktivasyonunda azalmaya yol açarak pAMPK/AMPK oranında anlamlı düşüşe neden oldu ( $p=0,044)$. p-AMPK/AMPK oranı remobili- 
zasyon sirasinda TVT uygulanan grupta immobilizasyon grubuna göre anlamlı ölçüde arttı $(p=0,001)$. Diğer yandan, immobilizasyonu takip eden dönemde sadece remobilizasyon uygulandığında p-AMPK/AMPK düzeyi kontrol grubundan veya immobilizasyon grubundan istatistiksel olarak farklı bulunmadı $(\mathrm{p}>0,05)$.

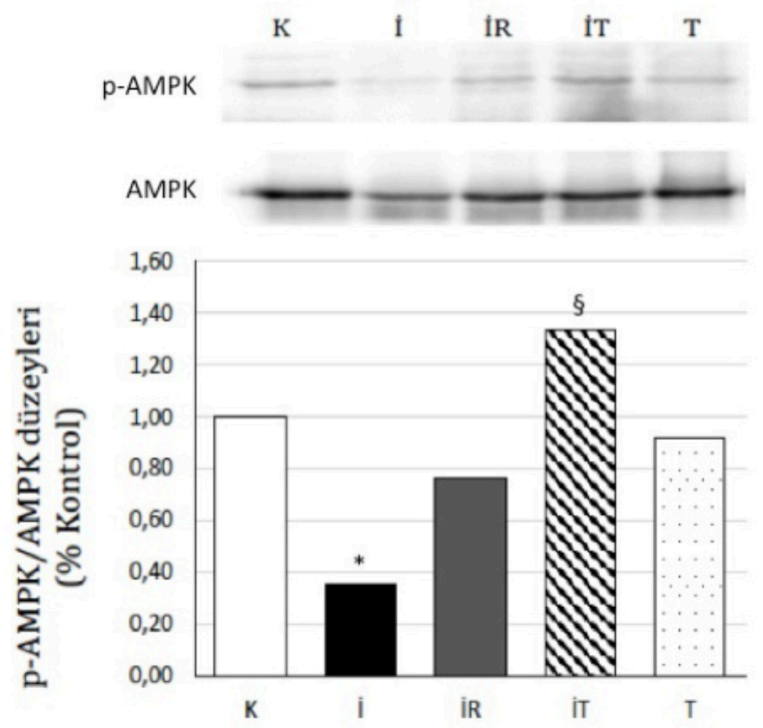

Şekil 2. İmmobilizasyon (I) ve immobilizasyon sonrası TVT (IT) uygulamasının sıçan soleus kasında AMPK fosforilasyonu üzerine etkisi. p-AMPK: forsorile AMPK, AMPK: total AMPK. * K'den $(p=0,044)$ ve $\S$ I'den farklı $(p=0,001)$. Gruplar sirası ile ( $\mathrm{n}=6$, her gup); K: kontrol, I: iki haftalık immobilizasyon, İR: iki haftalık immobilizasyonu takip eden bir hafta remobilizasyon, IT: iki haftalık immobilizasyonu takip eden remobilizasyon döneminde bir hafta TVT uygulanan grup, T: bir hafta TVT uygulanan grup.

\section{TARTIŞMA ve SONUÇ}

Bu çalışma, alçı yoluyla gerçekleştirilen immobilizasyonun kas atrofisi ve AMPK aktivasyonunda azalmaya neden olacağı ve toparlanma döneminde uygulanan TVT'nin ise AMPK aktivasyonunu artıracağı hipotezini test etmek amacı ile gerçekleştirildi. Çalışma sonuçları, iki haftalık bilateral alçının sıçan soleus kasında aktive AMPK (p-AMPK) düzeylerinde önemli ölçüde düşüşe yol açtığını gösterdi. Diğer yandan, iki haftayı takip eden bir haftalık toparlanma döneminde TVT uygulandığında, AMPK aktivasyonunun alçı grubuna göre anlamlı artış sağlandı.
$\mathrm{Bu}$ bulgular, bir spor yaralanması nedeni ile bir veya daha fazla ekstremitenin alçı veya atele alındığı immobilizasyon dönemini takip eden akut dönemde TVT uygulamasının, iskelet kası metabolik fonksiyonunun kazandırılmasında etkili olabileceğini düşündürmektedir.

AMPK, AMP ile aktive olan ve enerji düzeyini algllayan bir protein kinaz olup katalitik $\alpha$ ve düzenleyici $\beta$ ve $\gamma$ alt ünitelerinden oluşmaktadır $(1,21)$. AMPK'nin aktifleşmesi $\alpha$ alt ünitesinin Thr172 seviyesinde fosforillenmesi ile gerçekleşir (21). AMP'nin katalitik olmayan $\gamma$ alt ünitesine bağlanması, $\alpha$ alt ünitesindeki Thr172 fosforilasyonunu da içeren allosterik aktivasyona neden olur. Sonuç olarak, hücrede enerji harcamasının veya yeterli ATP üretiminin olmayışının göstergesi olan AMP/ATP veya $\mathrm{Cr} / \mathrm{PCr}$ oranının artmasının $\alpha$ katalitik alt ünitesinin Thr172 düzeyinde fosforilasyonu ile AMPK'nin aktifleşmesini sağladığı gösterilmiștir $(4,22)$.

AMPK, ATP üretimini sağlayan yolakların aktivasyonuna, ATP harcanan yolakların ise baskılanmasına neden olarak hücresel metabolizmada değișikliklere yol açar. Böylece AMPK bir yandan hücrenin yaşamını sürdürebilmesi için elzem olmayan hücre büyümesi ve proliferasyonu, glikojen, kolesterol, protein ve lipit sentezi gibi enerji harcamasını gerektiren metabolik süreçleri sınırlayarak enerjinin harcanmasını engellerken; diğer yandan da yağ asiti oksidasyonu ve glukoz transportunun artırılması gibi hücreye gerekli enerjinin sağlanması ile ilgili metabolik süreçleri aktive eder $(22,23)$. Bu çerçevede AMPK, iskelet kas hücresine glukoz alımında temel rol oynayan hücre içi sinyal proteini olarak işlev görerek GLUT4 düzeylerini artırır (24). Sıçan iskelet kasında AMPK aktivasyonunun metabolik sendromun yol açtığı; insulin direnci, ektopik lipit birikmesi ve kronik inflamasyon gibi birçok olumsuz değişimi engellediği gösterilmiştir (22). Çalışmalar AMPK aktivasyonunun sadece insülin direnci ve tip 2 diyabetin önlenmesi açısından değil, metabolik hastalıklar, lipogenez, kanser, Alzheimer gibi hastalıkların önlenmesi ve tedavisinde de rol oynayabileceğine dikkat çekmektedir (25). Dolayısıyla, iskelet kası AMPK düzeylerinin artırılmasının sağlıklı bir yaşamın sürdürülmesinde ciddi bir önemi bulunmaktadır. 
Siçanda kuyruktan asma yoluyla oluşturulan atrofi modelinde AMPK fosforilasyonunun ve enerji depolarının azaldığl; protein döngüsünün ise yıkım yönünde değiștiği bilinmektedir (13). Benzer şekilde nervus tibialisin kesilmesi yoluyla oluşturulan denervasyonun üçüncü gününde gastroknemius kasında AMPK ve GLUT4 düzeylerinin önemli ölçüde azalırken, AMPK aktivatörü olan AICAR enjeksiyonunun denerve siçan kasında GLUT4 düzeylerini koruduğu gösterilmiştir (26). Bizim çalışmamız ile, alçı yoluyla oluşturulan immobilizasyonun iskelet kasında AMPK aktivasyonunu azalttığı ortaya konulmuş oldu. AMPK'nin iskelet kasına glukoz alımındaki rolü göz önüne alındığında, uzun süreli immobilizasyonun iskelet kası metabolizmasını olumsuz etkileyerek insulin direncinde artmaya yol açması kaçınılmaz görünmektedir. Nitekim, farmakolojik bir AMPK indükleyici ajan olan AICAR'nin her gün tekrarlayan bir șekilde enjeksiyonunun sıçan iskelet kasında GLUT4 ve hekzokinaz enzim düzeyleri ve bazı mitokondrial enzim gen ekspresyonunu artırdığı (27), farelerde AMP/ATP oranını artıran $\beta$ guanidinopropionic asitten zengin gida verilmesi veya egzersiz yolu ile AMPK aktivasyonunun mitokondri biyogenezini artırdığı ve dominantnegatif AMPK'li (AMPK aktivasyonunun engellenmesi) farelerde ise bu etkinin oluşmadığ görülmüştür (28). Bu bulgular, özellikle immobilizasyon gibi iskelet kaslarının kullanılmadığı süreçlerde AMPK aktivasyonunu artıracak stratejiler geliştirilmesinin önemini ortaya koymaktadir.

Aerobik egzersizler AMPK aktivasyonu için temel fizyolojik strestir. Düzenli egzersizlerin mitokondri biyogenezini uyarması, GLUT4 düzeylerini artırması ve insulin direncini azaltması artan AMPK fosforilasyonu üzerinden gerçekleşmektedir (28). Çalışmalar egzersizin AMPK'yi aktive ederek iskelet kası glukoz taşıyıcılarınının hücre zarına translokasyonunu ve böylece hücre içerisine glukoz alımını artırdığını göstermiştir $(24,29)$. Egzersizin bir çok hastalığın tedavisinde oynadığı rolün altında AMPK aktivasyonunun önemli bir yerinin oldu$\breve{g u}$ bilinmektedir (30). Altı haftalık dayanıklılık koşusu antrenmanının yaşlı sıçanlarda iskelet kası p-AMPK, SIRT-1 ve anti apoptotic Bcl-2 düzeylerini artırırken Bax protein ekspresyounu azalttığı, egzersizin p-AMPK ve SIRT1 üzerinden anti-apoptotik sinyal yolaklarını uyararak yaşlanma ile kas morfolojisi ve ultra yapısında görülen değişiklikleri azalttığı ifade edilmiştir (31). Diğer yandan ileri düzeyde yaşlanma, zorunlu yatak istirahati veya immobilizasyon gibi egzersiz yapmanın fiziksel olarak mümkün olamadığ koşullarda AMPK indüklenmesi için alternatif stratejiler geliştirilmesi önem taşımaktadır.

Son yıllarda, tüm vücut titreşiminin (TVT) egzersizin yaptığı etkileri mimik ederek, kemik mineral yoğunluğu, kas kütle ve kuvvetini artırdığ iskelet kasında yağ infiltrasyonunu ve adipojenik gen ekspresyonunu azalttığı bildirilmiştir $(17,18)$. İmmobilizasyon sonrasındaki akut toparlanma döneminde TVT'nin etkinliğinin değerlendirildiği bu çalıșma, kasın metabolik fonksiyonunun kazandırılması için TVT'nin egzersize alternatif bir yöntem olup olamayacağı konusunda da bir fikir vermektedir. Çalışmamız, immobilizasyon sonrasinda bir hafta boyunca sadece remobilizasyon yapılan İR grubunda aktif p-AMPK/AMPK oranının immobilizasyon grubundan (İ) farklı olmadığını ( $\mathrm{p}>0,05)$, ancak bir haftalık remobilizasyon döneminde TVT uygulanan ITT grubunda iskelet kası p-AMPK/AMPK oranının İ grubuna göre anlamlı ölçüde arttığını gösterdi $(p<0,05)$. Böylece bu çalışmada ilk kez immobilizasyon sonrası TVT uygulamasinın iskelet kasında p-AMPK düzeylerini artırdığı ortaya konmuş oldu.

$\mathrm{Bu}$ çalışmada, sıçanlardan elde edilen soleus kasında RT-PCR yöntemi ile AMPK alfa katalitik ünitesi gen ekspresyonu da değerlendirildi. Her ne kadar AMPK mRNA düzeylerinde İ ve İR gruplarında azalma İT grubunda ise artış gözükse de, AMPK mRNA düzeylerindeki bu değişiklikler istatistiki olarak anlamlı değildi. Bu durum, immobilizasyon sonrasinda azalan $p$ AMPK/AMPK düzeylerinin remobilizasyon sirasinda TVT uygulaması ile artmasında fosforile olabilecek AMPK havuzunun artmasindan ziyade, fosforilasyona etki eden AMP/ATP oranındaki olası değişikliğin rol oynadığını düşündürmektedir. Gerek in vivo insan çalışmaları ve gerekse izole kas lifinde elde edilen çalışmalar titreşimin enerji tüketimini artırdığını göstermektedir (33-35). Tüm vücut titreşimi ayakta durmaya göre iskelet kası enerji harcamasında \%113 artışa yol açmıștır (34). 
Benzer şekilde, izole kas lifinde ATP tüketiminin titreşim varlığında önemli ölçüde arttığı görülmüştür (35). Diğer yandan bu çalışmada herhangi bir immobilizasyon oluşturmadan sadece bir haftalık TVT uygulanması p-AMPK/AMPK düzeylerinde bir değişikliğe yol açmamıştır ( $p>0,05)$. Bu durum TVT'nin AMPK aktivasyonu üzerine etkisinin immobilizasyona uğramış kasta ortaya çıktığını göstermektedir. İnsanda, ayak plantar fleksiyonda yapılan \%40 maksimal izometrik kontraksiyonda, özellikle kan akımının engellendiği durumda TVT varlığ $\mathrm{PCr}$ düzeylerinde anlamlı ölçüde düşüşe ve ATP harcamasında da \%60 üzeri artıșa neden olmuștur (33). Keza, aktif iskelet kasının sempatik vazokonstriksiyon üzerindeki inhibitor etkisi immobilizasyon koşullarında bozulmaktadır (36). Bu çalışmalar immobilizasyonun iskelet kas hücresinde yaratığı iç ortamın TVT varlığında AMP/ATP oranının artmasına neden olabileceğini düşündürmektedir.

Bu çalışmada TVT uygulamasının 2 haftalık immobilizasyonu takip eden dönemde yapılması spor yaralanmalarında sıklıkla uygulanan alçı, atel ve benzeri koşullarda karşılaşllacak durumların değerlendirilmesine olanak sağlamıștır. Diğer yandan, bu çalışma deseninde alçı ile oluşturulan immobilizasyon sirasinda TVT uygulaması mümkün olamadığından TVT uygulamasının immobilizasyonun p-AMPK/AMPK düzeylerinde neden olduğu azalmayı engelleyip engelleyemeyeceği merak konusudur. Özellikle zorunlu olarak yapılan uzun süreli yatak istirahatini gerektiren koşullarda TVT'nin kullanmama ile birlikte uygulanmasının iskelet kası metabolizması üzerine etkisi önemli bir klinik soru olarak karşımızda durmaktadır.

Sonuç olarak, bu çalışma iki haftalık bilateral bacak alçısının soleus kasında p-AMPK/AMPK düzeylerini düşürdüğünü $(p<0,05)$, toparlanma döneminde TVT uygulamasının ise AMPK aktivasyonunu artırdığını göstermiştir $(\mathrm{p}<0,05)$. Bu bulgular; özellikle yüksek frekanslı ve düşük genlikli titreşimin spor yaralanmaları nedeni ile, bir ekstremitenin alçı veya atele alınması gereken durumlarda, immobilizasyonun sonlandırılmasını takip eden ve yeterli şiddette egzersiz yapmanın mümkün olmadığı toparlanma sürecinde kas metabolik fonksiyonlarının daha hızlı kazanılmasında etkili olabileceğini düşündürmektedir.

Finansal Destek: $\mathrm{Bu}$ çalışma Hacettepe Üniversitesi Bilimsel Araștırmalar Birimi tarafından TDK-2015-7533 kodu ile desteklenmiştir.

\section{KAYNAKLAR}

1. Hardie DG, Carling D: The AMP-activated protein kinase--fuel gauge of the mammalian cell? Eur J Biochem 1997, 246(2):259-273.

2. Bergeron R, Russell RR, 3rd, Young LH, Ren JM, Marcucci M, Lee A, Shulman GI: Effect of AMPK activation on muscle glucose metabolism in conscious rats. Am J Physiol 1999, 276(5 Pt 1):E938-944.

3. Ojuka EO, Jones TE, Nolte LA, Chen M, Wamhoff BR, Sturek M, Holloszy JO: Regulation of GLUT4 biogenesis in muscle: evidence for involvement of AMPK and $\mathrm{Ca}(2+)$. Am J Physiol Endocrinol Metab 2002, 282(5):E1008-1013.

4. Ponticos M, Lu QL, Morgan JE, Hardie DG, Partridge TA, Carling D: Dual regulation of the AMP-activated protein kinase provides a novel mechanism for the control of creatine kinase in skeletal muscle. EMBO J 1998, 17(6):1688-1699.

5. Ruderman N, Prentki M: AMP kinase and malonyl-CoA: targets for therapy of the metabolic syndrome. Nat Rev Drug Discov 2004, 3(4):340-351.

6. Mikines KJ, Sonne B, Farrell PA, Tronier B, Galbo H: Effect of physical exercise on sensitivity and responsiveness to insulin in humans. Am J Physiol 1988, 254(3 Pt 1):E248-259.

7. Blair SN, Kohl HW, 3rd, Paffenbarger RS, Jr., Clark DG, Cooper KH, Gibbons LW: Physical fitness and all-cause mortality. A prospective study of healthy men and women. JAMA 1989, 262(17):2395-2401.

8. Booth FW, Roberts CK, Laye MJ: Lack of exercise is a major cause of chronic diseases. Compr Physiol 2012, 2(2):1143-1211.

9. Ojuka EO, Goyaram V: Mechanisms in exercise-induced increase in glucose disposal in skeletal muscle. Med Sport Sci 2014, 60:71-81.

10. Chen ZP, Stephens TJ, Murthy S, Canny BJ, Hargreaves M, Witters LA, Kemp BE, McConell GK: Effect of exercise intensity on skeletal muscle AMPK signaling in humans. Diabetes 2003, 52(9):2205-2212.

11. Wojtaszewski JF, Nielsen P, Hansen BF, Richter EA, Kiens B: Isoform-specific and exercise intensitydependent activation of 5'-AMP-activated protein kinase in human skeletal muscle. J Physiol 2000, $528 \mathrm{Pt}$ 1:221-226. 
12. Olsen RH, Krogh-Madsen R, Thomsen C, Booth FW, Pedersen BK: Metabolic responses to reduced daily steps in healthy nonexercising men. JAMA 2008, 299(11):1261-1263.

13. Yoshihara T, Machida S, Kurosaka Y, Kakigi R, Sugiura $\mathrm{T}$, Naito $\mathrm{H}$ : Immobilization induces nuclear accumulation of HDAC4 in rat skeletal muscle. J Physiol Sci 2016, 66(4):337-343.

14. Hamrick MW, McGee-Lawrence ME, Frechette DM: Fatty Infiltration of Skeletal Muscle: Mechanisms and Comparisons with Bone Marrow Adiposity. Front Endocrinol (Lausanne) 2016, 7:69.

15. Manthou M, Nohroudi K, Moscarino S, Rehberg F, Stein G, Jansen R, Abdulla D, Jaminet P, Semler O, Schoenau E et al: Functional recovery after experimental spinal cord compression and whole body vibration therapy requires a balanced revascularization of the injured site. Restor Neurol Neurosci 2015, 33(2):233-249.

16. Marin PJ, Rhea MR: Effects of vibration training on muscle strength: a meta-analysis. J Strength Cond Res 2010, 24(2):548-556.

17. Novotny SA, Mader TL, Greising AG, Lin AS, Guldberg $\mathrm{RE}$, Warren GL, Lowe DA: Low intensity, high frequency vibration training to improve musculoskeletal function in a mouse model of Duchenne muscular dystrophy. PLoS One 2014, 9(8):e104339.

18. Frechette DM, Krishnamoorthy D, Adler BJ, Chan ME, Rubin CT: Diminished satellite cells and elevated adipogenic gene expression in muscle as caused by ovariectomy are averted by low-magnitude mechanical signals. J Appl Physiol (1985) 2015, 119(1):27-36.

19. McGee-Lawrence ME, Wenger KH, Misra S, Davis CL, Pollock NK, Elsalanty M, Ding K, Isales CM, Hamrick MW, Erion JR et al: Whole-body vibration mimics the metabolic effects of exercise in male leptin receptor deficient mice. Endocrinology 2017.

20. Dönmez G, Doral MN, Suljevic S, Sargon MF, Bilgili H, Demirel HA: Effects of immobilization and whole-body vibration on rat serum Type I collagen turnover. Acta Orthopaedica et Traumatologica Turcica 2016, 50(4):640-647.

21. Hardie DG: AMPK and autophagy get connected. EMBO J 2011, 30(4):634-635.

22. Hardie DG: Role of AMP-activated protein kinase in the metabolic syndrome and in heart disease. FEBS Lett 2008, 582(1):81-89.

23. Mantovani J, Roy R: Re-evaluating the general(ized) roles of AMPK in cellular metabolism. FEBS Lett 2011, 585(7):967-972.

24. O'Neill HM: AMPK and Exercise: Glucose Uptake and Insulin Sensitivity. Diabetes Metab J 2013, 37(1):1-21.
25. Rana S, Blowers EC, Natarajan A: Small molecule adenosine 5 '-monophosphate activated protein kinase (AMPK) modulators and human diseases. J Med Chem 2015, 58(1):2-29.

26. Paulsen SR, Rubink DS, Winder WW: AMP-activated protein kinase activation prevents denervationinduced decline in gastrocnemius GLUT-4. J Appl Physiol (1985) 2001, 91(5):2102-2108.

27. Winder WW, Holmes BF, Rubink DS, Jensen EB, Chen M, Holloszy JO: Activation of AMP-activated protein kinase increases mitochondrial enzymes in skeletal muscle. J Appl Physiol (1985) 2000, 88(6):2219-2226.

28. Zong H, Ren JM, Young LH, Pypaert M, Mu J, Birnbaum MJ, Shulman GI: AMP kinase is required for mitochondrial biogenesis in skeletal muscle in response to chronic energy deprivation. Proc Natl Acad Sci U S A 2002, 99(25):15983-15987.

29. Jessen N, Goodyear LJ: Contraction signaling to glucose transport in skeletal muscle. J Appl Physiol (1985) 2005, 99(1):330-337.

30. Richter EA, Ruderman NB: AMPK and the biochemistry of exercise: implications for human health and disease. Biochem J 2009, 418(2):261-275.

31. Liao ZY, Chen JL, Xiao MH, Sun Y, Zhao YX, Pu D, Lv AK, Wang ML, Zhou J, Zhu SY et al: The effect of exercise, resveratrol or their combination on Sarcopenia in aged rats via regulation of AMPK/Sirt1 pathway. Exp Gerontol 2017, 98:177-183.

32. Wirth F, Schempf G, Stein G, Wellmann K, Manthou M, Scholl C, Sidorenko M, Semler O, Eisel L, Harrach R et al: Whole-body vibration improves functional recovery in spinal cord injured rats. J Neurotrauma 2013, 30(6):453-468.

33. Zange J, Haller T, Muller $\mathrm{K}$, Liphardt AM, Mester J: Energy metabolism in human calf muscle performing isometric plantar flexion superimposed by $20-\mathrm{Hz}$ vibration. Eur J Appl Physiol 2009, 105(2):265-270.

34. Rittweger J, Schiessl H, Felsenberg D: Oxygen uptake during whole-body vibration exercise: comparison with squatting as a slow voluntary movement. Eur J Appl Physiol 2001, 86(2):169-173.

35. Wang Y, Kerrick WG: The off rate of $\mathrm{Ca}(2+)$ from troponin $\mathrm{C}$ is regulated by force-generating cross bridges in skeletal muscle. J Appl Physiol (1985) 2002, 92(6):2409-2418.

36. Mortensen SP, Morkeberg J, Thaning P, Hellsten Y, Saltin B: Two weeks of muscle immobilization impairs functional sympatholysis but increases exercise hyperemia and the vasodilatory responsiveness to infused ATP. Am J Physiol Heart Circ Physiol 2012, 302(10):H2074-2082. 